\title{
Eco-Innovation in the Corporations Operating in the International Market
}

\author{
Tatiana Dilma Fernandes de Oliveira Medeiros ${ }^{1} \&$ Claudio Pitassi ${ }^{2}$ \\ ${ }^{1}$ Master by Ibmec, Rio de Janeiro, Brazil \\ ${ }^{2}$ School of Administration, Ibmec, Rio de Janeiro, Brazil \\ Correspondence: Tatiana D. Fernandes de Oliveira Medeiros, Master in Business Administration, Sacramento, \\ CA, United States of America. Tel: 1-916-591-7611.
}

\author{
Received: December 31, 2017 Accepted: February 8, $2018 \quad$ Online Published: February 26, 2018 \\ doi:10.5539/jms.v8n1p75 URL: https://doi.org/10.5539/jms.v8n1p75
}

\begin{abstract}
This paper aims at analyzing which is the eco-innovation level of the companies operating in the international market according to the Sustainability Innovation Cube (SIC) model developed by Hansen, Grosse-Dunker, \& Reichwald (2009), so as to reveals an element of competitiveness in international market; at wit, BRF, Bunge, Docol, Intelbrás and Tigre. Also, identify how the issues of sustainability and innovation are understood in the corporations operating in the international market and review the motivations to the main programs and existing eco-innovation projects in the corporations studied. In this regard, a qualitative study of exploratory nature was carried out together with the five companies, by means of semi-structured interviews, observations, websites, internal documents, public notice, regulations, among others, which were reviewed using the technique of content analysis in depth. Data assessment was elaborated through the correlation of the theoretical background, of SIC tool and the information collected from the field. The outcomes enables to confirm that the companies surveyed have a high rate of eco-innovation, which exception of BRF, and discloses that eco-innovation contributes to enhance competitiveness in the operations of the companies in international market too.
\end{abstract}

Keywords: eco-innovation, competitiveness, international market

\section{Introduction}

"Nowadays, we are experiencing a severe socio-environmental crisis at planetary scale, and the magnitude of this crisis makes the demand for fast and assertive actions urgent by the side of several sectors of Society" (Maniglia \& Costa, 2012, p. 37).

The worsening of environmental deterioration and the decline of biodiversity, the increase of planet temperature and the persistence of social unfairness illustrates the depletion of business logic connected to industrial economy (Gilding, 2014) and strengthens the argument that sustainability has become a long way to keep human societies within a "safe operational space" and to safeguard our planet for the current and future generations (Leach et al., 2012).

As long as Brundtland (1997) sets up the principle of sustainability, it is clear that economic sustainability cannot be achieved without also reaching environmental sustainability and social sustainability. The example of the recent accident in the dam of Mineradora Samarco (Mining") in the Municipality of Mariana (MG) in Brazil is iconic regarding how an accident has economic impact (fines, operations stoppage) environmental (destruction of flora and fauna, water pollution) and social (deaths and impacts in survivorship conditions in the municipalities affected).

Undoubtedly, companies highly influence economics and life in general. Sustainable development is not possible without a sustained development of the companies. Corporate management is therefore, a crucial actor in the formation of the future development of the companies, as well as the economics and society (Schaltegger, Freund, \& Hansen, 2012).

The aforementioned scenario proves that the actual form to carry out business, grounded in the unthinking consumerism, in the programed obsolescence as well as the irresponsible items disposal consumed in the environment, needs to be changed (Bocken \& Short, 2015). Yet, it is clear that sustainable development, environmentally balanced and socially inclusive may only be possible by means of innovations introduction 
(Aghion et al., 2009).

The eco-innovation field study arises as the result of the convergence of the concepts of both innovation and sustainability (Huppes et al., 2006). The literature review points out that there is no agreement about the comprehensiveness of the concept of eco-innovation regarding the level of analysis of the company, being that major models disregards social dimension, as the environmental dimension makes economic sense to profit corporations (Dyllick \& Hockets, (2002), mentioned by Munck, Galleli, \& Souza, 2013).

Recent surveys in the management area of corporations underlines the increasing interest by the issue of eco-innovation, suggesting the need of theoretical and empirical surveys regarding contribution of corporate corporations for the sustainable development (Adams et al., 2015).

The companies which operate in the international market, as a result of commitments assumed together with the consenting national and international authorities, before the greenhouse gases emissions in the meetings in Kyoto \& Marrakesh too (UNFCC, 1998) and face to it exposure to consumer markets of developed countries, as a matter of course more demanding regarding the sustainability actions of the companies, have special interest in adopting sustainable models in carrying out their business (FGV, 2011).

The sooner the corporations start to see the sustainability as their main challenge and as opportunity, the more competitiveness and the better will be the chance for them to survive (Tachizawa, Takeshy, \& Pozo, 2007).

The primary purpose of this survey is (1) analyze which is the level of eco-innovation of companies which operate in the international market according to the Sustainability Innovation Cube (SIC) model developed by Hansen, Grosse-Dunker, \& Reichwald (2009), in order to reveal a factor of competitiveness in the international market; at wit, BRF, Bunge, Docol, Intelbrás and Tigre. Are intermediate objectives (2) identify how the issues like sustainability and innovation are noticed in corporations which operate in international market and (3) analyze the motivations to the main programs and existing eco-innovation projects in the corporations studied.

The survey is delimited to measuring the level of eco-innovation by means of SIC-Sustainability Innovation Cube, tool developed by Hansen, Grosse-Dunker, \& Reichwald in 2009. Oslo Manual will also be used as well as the companies' programs and projects as support to classify the performance of the companies surveyed; thus, it will be possible to verify whether the companies with higher level of eco-innovation are more competitive in their performance in the current international market. The population highlighted in the study is managers who have been operating directly in eco-innovation in the companies selected which operate in international market. Directors and operational employees have not taken part in the survey. Survey will be limited to companies BRF, Bunge, Docol, Intelbrás and Tigre. Clients, suppliers and competitors companies surveyed are out of survey scope.

This study is relevant before the advent of new scenarios, sustainable sayings, which correspond to new habits and attitudes that may contribute to the creation of principles of life quality, converting the political, social and economic systems which support the economic growth based on consumption (Queiroz, 2014).

\subsection{Sustainability}

The contemporary societies' policies are more and more challenged with a great variety of ecological crises, including weather changes, loss of biodiversity, water shortage, deforestation and pollution (Gilding, 2014).

"Our human society and our economics are so big now that we have surpassed the threshold of capacity of the planet to support us and it has been running out. Our current model of economic growth is taking this system - to which we trust to our present and future prosperity—downhill" (Gilding, 2014, p. 15).

The mindset aims to guide mankind, as it could not be otherwise, to a historical moment in which the own survival basic conditions have been thrown into doubt, becoming structural changes indispensable and urgent in human action (Maniglia \& Costa, 2012).

Current approaches of sustainability with focus, mostly in efficiency, in enhancement of yields and "ecologization" of supply chain and products is the first important step in decline of impacts of production and the consumption. Nevertheless, the increasingly demand is overcoming a lit such as enhancement and innovations, and those initiatives may facilitate effects: where is there efficiency to increase consumption? (Druckman et al., 2011, cited by Bocken \& Short, 2015).

The concept of sustainability was initially defined by Brundtland Report in 1987, as a political concept: "Sustainable development is development that meets the needs of the present without compromising the ability of future generations to meet their own needs" (Brundtl \& Committee, 1987).

Boken \& Short (2015) introduce the justifications of economic system to surpass the threshold of the 
environmental, social and economic resources:

- Need of short term return by the side of the companies;

- Mass consumer markets;

- Competition for price;

- Consumers searching for innovations and varieties;

- Status and prestige resulting from fashion;

- Effects of slow growth and at long term;

- Fast obsolescence of IT \& Telecom products.

Simultaneously, several discussions over the issue unfold how a broad and politically carried concept could be adapted and operationalized from the economic point of view. In the corporate world, it is interpreted many times as triple bottom line, defending the integration of economic, social and environmental dimensions (Hansen, Grosse-Dunker, \& Reichwald, 2009).

"The economic sustainability supposes the increase of production and consumption efficiency with growing economics of natural resources, with highlight to permissive resource like the fossil sources of energy and the delicate but badly distributed resources, such as water and minerals. It is about what some name as eco-efficiency, what supposes a continuous technological innovation that lead us to get out of energy fossil cycle (coal, oil and gas) and to enlarge the dematerialization of economics" (Nascimento, 2012, p. 55).

The social dimension has been approached more recently. Boken \& Short (2015) describe that social sustainability will occur when the economics becomes more stable and sustainable, as it will generate more fair social aspirations and business models that aggregate human value further to environmental. The same authors provide some tools to reach sustainability by means of sufficiency:

- Property share;

- Services to reduce consumption of resources;

- Moderate promotions and sales marketing;

- Extend products life cycle;

- Reuse;

- Deals with full life cycle.

Boken \& Short (2015) and Melo Neto \& Brennand (2004) point out that there is social sustainability when the companies have proposition and capture of value in society, that is, of the value as organization grounded on the local development and social value. Also, it is possible to find definitions and tools in Instituto Ethos ("Institute Ethos") to understand and incorporate the concept and social responsibility.

According to Murad, Amaral, \& Boff (2013), what is in cause by the proposal and requirement of sustainability is the relation between economics and the environment: the current interest in this socioeconomic cutout is grounded on the high likelihood that the weather changes affect the way how contemporary industrial societies carry out their economies.

This strong probability has been generating technological changes proposals in the economies that change the production and consumption standards, challenge that regards philosophy, science, economics and our personal values (Gilding, 2014).

It is important to highlight that, according to Freitas (2014, p. 4701), "when a public or private company discloses to the great audience positive environmental practices however having adverse actions to the socio-environmental interests that it discloses, there is a green make-up washing, the so-called greenwashing". This term is applied when environmental and social concepts used to form a public responsible image of a company do not match with their actual management, sometimes negative and that causes problems and degradation in the environment, social problems or health and safety in different levels (Schaltegger, Freund, \& Hansen, 2012).

To comply with the agenda of sustainability, companies demand innovative responses: or do what we make better, or do what we do in a different way, that is, make social and environmental changes which can be differentiated by innovation (Adams et al., 2015). 


\subsection{Innovation}

Innovation is driven by the capacity of setting relations, detect opportunities and take advantage of them, not consisting only in the opening of new markets. It also means new forms of serving to markets already set out and mature (Tidd \& Bessant, 2015).

"Innovation only produces major economic impacts when it is largely disclosed among companies, sectors and regions, triggering and creating new markets" (Tigre, 2006, p. 71).

Although the benefits of innovation to industrial growth and economic progress have been identified since 1776 by economics thinkers like Adam Smith, Karl Marx, Stuart Mill, Alexis de Tocqueville and other remarkable scholars, it was Joseph Schumpeter (1883-1950) who, from 1911 on, not only bring the technological innovation to the center of the debate on economic development but also provide a broad perspective innovation involving imitation, experimentation, adaptation of processes and products, new organizational arrangements, new sources of energy and raw materials, as well as P\&D. Schumpeter did not restrict to himself to emphasize the role of individual entrepreneurs; in the second phase, he recognized the importance of large innovative companies in economic development of countries (Figueiredo, 2013).

The competitive advantage of innovation may arise from size or equity, among other factors, as the gradually changing scenario in favor of those corporations that manage to mobilize knowledge and technological advances and conceive the creation of news in their supplies (product/services) and in the forms as they create and launch them. Almost all economic growth that took place since XVIII century can be attributed to innovation (Tidd \& Bessant, 2015).

\subsubsection{Classifications of Innovation}

It is possible to find out in literature several authors who define and characterize innovation, but the points and authors relevant to this survey will be highlighted. According to Tidd \& Bessant (2015), there are four dimensions of innovation: (i) Innovation of Product: Changes in what (products/services) the company offers. (ii) Innovation of Process: Changes in the form in which the products/services are created and delivered. (iii) Innovation of Position: Changes in the context in which products/ services are introduced. (iv) Innovation of Paradigm: Changes on the mental model subjacent that drives what the company does. To those authors, the " 4 Ps" of innovation are shaped.

To Tigre (2006), there are four types of innovations: technological, incremental (enhancements and daily modifications), radical (discontinuous leaps in technology and products processes), new technological system (comprehensive changes which affect more than one sector and give rise to new economic activities), and new techno-economic paradigm (changes that affect all economics involving technical and organizational changes, changing products and processes, creating new industries and setting out innovations records for several decades.

To Magretta (2002), cited by Oroski (2013), there is also innovation in business model, essential for the success of an organization, representing a new or a better form of creating and capturing value to corporations, generating new demands and sources of income.

\subsubsection{Innovative Process}

"The uncertainty is characterized not only by the absence of relevant information a priori, but also by the impossibility of precisely outline the consequences and outcomes prior to the survey and testing activities appropriately" (Figueiredo, 2013, p. 38).

"Different sources of technology and learning, both of internal and external origin, are used by corporations to launch new products, enhance processes, adopt new methods of organizational management and expand competitiveness" (Tigre, 2006, p. 93).

Innovation, different from technologies, is a process created when carrying forward an idea, reviewing and refining it, built different lines of "mass of knowledge" and create a product, a process or useful service. Innovation comes from many difference directions and, should we want to duly administrate it, such diversity cannot be ignored (Tidd \& Bessant, 2015).

\subsubsection{Technological Capacity}

Technological capacity — or base of knowledge - is a set of resources of cognitive nature. This is the intangible asset, which is not displayed in the companies' balance sheets, but which is able to define the distinctive performance in the market. It is grounded on the technological capacity that companies may perform production activities (of goods and services) and innovation (Figueiredo, 2013, p. 4). 
To Bell \& Pavitt (1995), technological capacities are not acquired as an automatic sub product of investment and production activities but generated by means of conscious and continuous investment. The capacity of a nation to promote and manage the technological change is crucial for the capacity of their companies and to their survival and growth in international market.

It is important to highlight that together with the technological capacity, the dynamic and absorptive capacities are mashed. The dynamics capacity refers to key role of strategic administrations in form of adapting, integrating and reconfiguring internal and external organizational abilities. Resources and functional competences are to correspond to the demands of a market change, that is, it is the capacity of renew competencies so as to reach the changes in the environment (Teece, Pisano, \& Shuen, 1997).

To Cohen \& Levinthal (1990), absorptive capacity is a construction comprised by three dimensions: Re-knowledge of Value, Assimilation and Application. Define that the capacity of absorption is the capacity pertaining to an organization to recognize the value of new external knowledge, assimilate it and apply it for commercial purposes. The very same authors consider that innovation is generated by means of the organization learning process (dependent on records) and that the capacity of absorption is comprised from a set of previous knowledge.

Schumpeter (1961) explains the economic development through his theory of "creative destruction": With it, consumer changes its habit of purchasing, that is, products or old habits are replaced by the re-invented ones. Thus, Schaltegger \& Wagner (2008) understand that the sustainable entrepreneurs should destroy the methods of production and the products, services and conventional consumption standards, replacing them by new possibilities such as products with high levels of environmental and social quality. This way, they will create the dynamics of sustainable market of progress. However, we observe that innovation, according to the authors studied, is still addressed to consumption, that is, produce more with less.

In any event, the companies have been motivated to find ways to reach sustainable development and economic growth, that is, eco-innovation. Thus, in the transition to sustainability, sustainable innovation has been helping companies and has been receiving considerable interest from scholars, managers and politicians. It, which involves make intentional changes in the philosophy and in values of organization, as well as in their products, processes or practices, meets specific purpose of creating and noticing social and environmental value, further to providing economic returns (Adams et al., 2015).

\subsubsection{Eco-Innovation}

Eco-innovation is defined by European Committees (CE, 2008), cited in Boons et al. (2013, p. 2) as "the production, assimilation or exploration of an innovation of the products, processes of production, services or in the management and business methods, which aim, in the whole life cycle to prevent or considerably reduce the environmental risk, pollution and other negative impacts of the use of resources (including energy)".

Based on the brief definition of eco-innovation by Carrillo-Hermosilla, Del Rio, \& Konnola (2010), cited in Boons et al. (2013, p. 2), sustainable innovation can be defined as "innovation that improves performance of sustainability, including ecological, economic and social criteria in this performance". Despite of the divergences about the accurate definition of the term, it is typically in the sense that eco-innovation could be developed by companies or non-profit corporations, or maybe traded in the markets, with its nature of being technological, organizational, social or institutional (Cai \& Zhou, 2014).

Sustainability is a challenge that demands the change of relation with the natural resources, rethinks the forms of production and use of materials and, at last, calls into consumption standards. On the side of the supply, this transition towards more sustainable systems mainly depends, on eco-innovation, that is, the capacity of the companies to develop new methods, products and/or processes which favor environment and contribute to environmental sustainability (Epicoco et al., 2014).

Eco-innovation includes new processes or enhanced and products, technologies, services and business models which are beneficial to environment or avoid negative environmental impacts (Hansen \& Klewitz, 2012).

In developed countries, the companies are more and more conscious about the potential benefits of enhancement in environmental performance. The European Commission adopted an action plan about the production and sustainable consumption in the context of Strategy of Lisbon (2008), a more recent European program, more strictly focused on eco-innovation, namely eco-innovation of Action Plan (EcoAP), also pursues decline in pressure over the environment by means of innovation in the ambit of Strategy of Europe 2020 (Triguero, Moremo-Mondejar, \& Davia, 2013), among other strategies used by several countries.

But, "as far are we are concerned, few studies manage to distinguish the different types of eco-innovation 
bordered by Oslo Handbook of OCDE (2005): process, product and organization" (Triguero, Moremo-Mondejar, \& Davia, 2013, p. 25). In spite of asserting that the classifications are clear and simple (Triguero, Moremo-Mondeja, \& Davia, 2013), Oslo Manual stresses the importance of analyzing the eco-innovation activities under an evolutionary perspective, what would allow us identify eco-innovative, not only in strategic form, but also passively.

It is possible to classify the environmental innovation determinants into three groups: factors on the side of the supply, factors on the side of the demand and environmental politics. Such a classification allows considering the influence of the technological advance and search of the attraction factors together with the environmental political and institutional system (Triguero, Moremo-Mondejar, \& Davia, 2013).

Eco-efficiency denotes a relation between the economic benefits and ecologic burdens by means of forms and options of eco-innovation, comprising several practices that increase efficiency of resources through the matching of economic value with environmental performance (Levidow et al., 2016).

While the identification of the eco-innovation benefits in companies is a popular issue in literature, there are many questions in developing countries that remain without answer, as eco-innovation is a strategy addressed to provide value to business to the clients which contribute to sustainable development and to reduce costs and environmental impacts (Cai \& Zhou, 2014). Nevertheless, each organization model has means and specific needs to develop eco-innovation.

It is worth highlight that eco-innovation is a journey within corporations: [...] must be incorporated as part of the way that a corporation carries out its business, instead of seen as something "beyond" its business practices. Managers must consider the best form to develop those innovations addressed to sustainability according to its business model (Roscoe \& Cousins å Lamming, 2016, p. 1949).

In this paper, a tool practice to assess the level of eco-innovation of the companies operating in international market was chosen, Sustainability Innovation Cube (SIC) for sustainability effects of framing innovations in order to better advise the managers. SIC aims at guiding organization in the choice of the most appropriate methods to assessment of sustainability, being a meta method. Aims to provide guidelines to corporations so that the methods used in the assessment and the report of the activities addressed to sustainability are the most proper. Thus, SIC is a macro model from which complementary models help corporations reach their goals. The model includes the three dimensions: focus, life cycle and types of innovation (Hansen, Grosse-Dunker, \& Reichwald, 2009).

To Hansen, Grosse-Dunker, \& Reichwald (2009), at the first place, following the concept of sustainability development from a business perspective, take advantage of the concept de triple bottom line allows differencing the economic, environmental and social effects aspects (dimension focus). Nevertheless, this dimension would be too vague and therefore improper to articulate sustainability effects. Thus, it is necessary to incorporate effects of products and technologies in the distinct phases of their physical life cycle, termed dimension life cycle. Thirdly, literature reveals that, by increasing the contents of services and products, one may induce significant positive effects of sustainability. Thus, the technological perspective would be far narrow to access potential innovations of sustainability, so it relates with this aspect dimension type of innovation.

Based on the three constitutional dimensions (of need, focus and life cycle), a generic model named "Sustainability Innovation Cube" (SIC) was developed. It is split into 27 individual areas which points out where the sustainability effects potentially may arise, that is, the relation among the 3 dimensions ( 3 aspects of dimension of need $x 3$ aspects of dimension of cycle of visa $x 3$ aspects of dimension of focus). It aims at displaying corporations which are the potential negative impacts of their products and processes and pointing out forms of measuring them. Those areas can be considered as targets to be driven by innovation management (Hansen, Grosse-Dunker, \& Reichwald, 2009), being this tool used in this paper. 


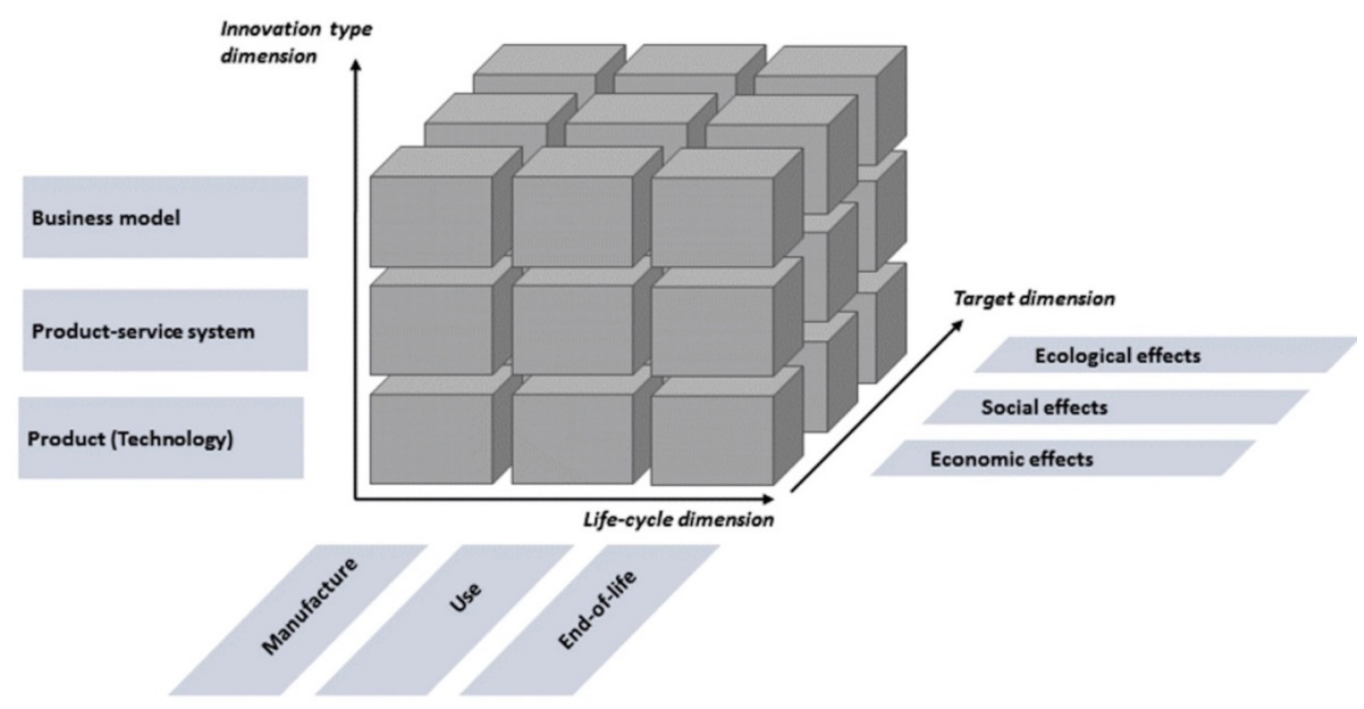

Figure 1. The Sustainability Innovation Cube (SIC)

Source: Hansen, Grosse-Dunker \& Reichwald (2009).

This model supports the companies seeking for considerations costs benefits, however does not allow them identify and quantify effects of sustainability in every 27 areas of sustainability, as it does not define criteria nor specific procedures. Those assessments are used to provide a base to decision taking in innovation management, as the SIC model is necessary as current assessment method, but may diverge internally in companies, and must be pre-defined in the focus of survey (Hansen, Grosse-Dunker, \& Reichwald, 2009).

\section{Method}

The method used in the Investigation phase was the study of multi-cases (Yin, 2003), with qualitative approach (Creswell, 2010), addressed to companies operating in the international market, searching their history of economic, environmental and social sustainability. The epistemological positioning of survey is the constructivist philosophical conception. To Creswell (2010), this survey aims at trust the maximum as possible in the views that the participants have from the situation which is being studied.

The present study takes into consideration the supposition of the importance of eco-innovation in corporations who operate in the foreign trade and that contributes to competitiveness in international market. That is why the best method is the qualitative, as the aim is a study in depth of the cases to analyze the phenomena of eco-innovation within the companies in the voice of the businessmen that experience this challenge. The tool applied to measure the level of eco-innovation in the companies is the SIC developed by Hansen, Grosse-Dunker, \& Reichwald, 2009.

Primarily information was gathered, built by means of semi-structured interviews (Fontana \& Frey, 1994) with companies' managers who operate in international market and secondary information by means of companies' website together with internal documents, such as public notice, regulations, among others. Also, documents were collected regarding consenting authorities who interfere directly in the level of eco-innovation of each company surveyed, among other data sources as photos and videos.

The interviews were made between April 2016 and June 2016, with average duration of 40 minutes. The carry out of the interviews was made as follows: first, looking to investigate particularities of each company; after that determine the view that each company has regarding sustainability, innovation and eco-innovation; afterwards, analyze the operations of companies and the programs and projects which identify in eco-innovation; at last, investigate the level of eco-innovation taking as base the 27 dimensions of SIC, as well as their contribution in the penetration in international market. The interviews were recorded and after that written out.

Information treatment was made with a deep analysis of the content, correlating the theoretical referential, which discloses the existence of few materials about the subject, specifically few instruments addressed to investigation of those phenomena in the Brazilian context, and the information collected from the field. Contact was made with the author of the tool used SIC; however, methodology was not provided, nor the tool of analysis, only other articles written. To help in the accomplishment of the information analysis, Oslo Manual was used as support, to classify and measure the types of innovation. 
The Brazilian corporations that operate in the international market were chosen by the differentiated profile of each one and also by the opening facility to this survey. According to Gil (2009), in the sample of accessibility, the surveyor selects the cases to which it may access, considering that they represent the universe analyzed.

Find below the Brazilian corporations which take part in the present survey:

BRF: Food Industry-Meat. Assessment made by interview made with the BRF senior analyst of sustainability (E1), being in the position for three years and three months, who displayed not having specific knowledge in eco-innovation.

Bunge: Food industry. Assessment was by interview made with the export manager (E2) and manager of innovation (E3), both with over five years in the position in Bunge. Displayed much knowledge in eco-innovation and searched to apply the programs and projects according to the needs and evolution of the company.

Docol: Sanitary metal industry. Assessment was by the interview made with the manager and corporate marketing for four years in the position in Docol (E4), who displayed in depth knowledge in eco-innovation and submitted several programs, projects and principles which support the core of the company.

Intelbrás: Industry of safety equipment, Telecom and networks. Assessment was by the interview made with the quality manager (E5), environment and compliance, for twenty-six years in the position in Intelbrás, who displayed no knowledge in eco-innovation; however, much engagement in enhancing the processes and products of the company regards innovation with sustainability, further to provide several supporting materials.

Tigre: Pipes and connection industry. Assessment was by interview made with the expert in innovation for four years in the position in Tigre (E6), who displayed to have knowledge in eco-innovation.

The restrains of the method chosen (qualitative) are: little systematic, difficulty to organize information and match information from different people and different corporations, difficulty to carry out interviews, difficulty to keep the focus of the analysis (start, mid and end) and the choice of the participants, as they must have direct relations of interest in the survey.

\section{Results}

In this chapter, information collected in the field survey will be introduced. Firstly, the institutional information will be submitted, the characteristics and relevant information of the five participating companies of survey, so that next to be submitted the information collected in the interviews and analyses. The programs and projects which support the analysis of the companies were identified in the material transferred by them and also in interviews. After the analysis of the material, the programs and projects which most identify or got closer to eco-innovation were selected to contribute to the study.

\subsection{Companies Surveyed}

Table 1. Characteristics

\begin{tabular}{|c|c|c|c|c|c|}
\hline & BRF & Bunge & Docol & Intelbrás & Tigre \\
\hline $\begin{array}{l}\text { Institutional } \\
\text { Information }\end{array}$ & $\begin{array}{l}\text { It is one of the biggest food } \\
\text { companies worldwide } \\
\text { created from the association } \\
\text { between Sadia and } \\
\text { Perdigão, two robust } \\
\text { companies of food market, } \\
\text { in } 2009 \text {. For } 82 \text { years. It has } \\
\text { been producing food and is } \\
\text { one of the global leaders in } \\
\text { export of animal protein and } \\
\text { produce food to over } 150 \\
\text { countries in the five } \\
\text { continents. }\end{array}$ & $\begin{array}{l}\text { In } 1818 \text {, Bunge \& Co } \\
\text { was founded in } \\
\text { Amsterdam, Holland, to } \\
\text { commercialize products } \\
\text { imported from colonies } \\
\text { and grains. Start in } \\
\text { Brazil was as partner of a } \\
\text { newly-created mill in the } \\
\text { city of Santos, passing } \\
\text { through the launching } \\
\text { pioneer of edible vegetal } \\
\text { oil, margarine and } \\
\text { manufacturing } \\
\text { technologies of fertilizer } \\
\text { up to benefits provided } \\
\text { to expansion of soya } \\
\text { crops in the country and } \\
\text { the precision farming }\end{array}$ & $\begin{array}{l}\text { The company started in } 1956 \text {, } \\
\text { in Jaraguá do Sul, Santa } \\
\text { Catarina, and currently its } \\
\text { industrial plant is located in } \\
\text { Joinville, as well as its } \\
\text { training center with } 720 \mathrm{~m}^{2} \text {, } \\
\text { distribution facility with over } \\
4 \text { mil } \mathrm{m}^{2} \text { and administrative } \\
\text { center with a building of } 2.130 \\
\mathrm{~m}^{2} \text {. }\end{array}$ & $\begin{array}{l}\text { Founded in } 1976, \\
\text { Intelbrás is a } \\
\text { Brazilian company } \\
\text { that operates in the } \\
\text { areas of safety, } \\
\text { Telecom and } \\
\text { network, and with a } \\
\text { technology that } \\
\text { reaches more than } \\
20 \text { countries to } \\
\text { which it exports. } \\
\text { Currently, Intelbrás } \\
\text { group has five } \\
\text { industrial unit: } \\
\text { Headquarters, } \\
\text { Branch São José SC, } \\
\text { Branch Palhoça SC, } \\
\text { further to Branches } \\
\text { in Minas Gerais and } \\
\text { in Amazonas. }\end{array}$ & $\begin{array}{l}\text { Founded in } 1941 \text { by } \\
\text { Hansen family, it is } \\
\text { a Brazilian } \\
\text { multinational, } \\
\text { leader in the several } \\
\text { markets in which it } \\
\text { operates. The brand } \\
\text { offers products that } \\
\text { meet the building } \\
\text { market, } \\
\text { infrastructure, } \\
\text { irrigation and } \\
\text { industrial. The } \\
\text { group is present in } \\
\text { nearly } 40 \text { countries, } \\
\text { has seven thousand } \\
\text { employees, nine } \\
\text { plants in Brazil and } \\
\text { thirteen overseas. }\end{array}$ \\
\hline
\end{tabular}




\begin{tabular}{|c|c|c|c|c|c|}
\hline $\begin{array}{l}\text { Programs } \\
\text { and/or Projects }\end{array}$ & $\begin{array}{l}\text { ReciclAção/Volunteers } \\
\text { BRF/SSMA (health, safety } \\
\text { and environment) }\end{array}$ & $\begin{array}{l}\text { Bunge natureza (“Bunge } \\
\text { nature”) /IPAS (initiative } \\
\text { pro sustainable food) } \\
\text { /soya Plus) }\end{array}$ & $\begin{array}{l}\text { Educational } \\
\text { program/salvágua (“Save } \\
\text { Water”)/planeta água ("Water } \\
\text { Planet”) }\end{array}$ & $\begin{array}{l}\text { Junior } \\
\text { achievement/pro } \\
\text { Brejarú/preserve }\end{array}$ & $\begin{array}{l}\text { Trata Brasil ("Treat } \\
\text { Brazil") /water } \\
\text { sustainable } \\
\text { use/ICRH ( Carlos } \\
\text { Roberto Hansen } \\
\text { Institute) }\end{array}$ \\
\hline $\begin{array}{l}\text { Innovation } \\
\text { sustantainable - } \\
\text { Eco-innovation }\end{array}$ & $\begin{array}{l}\text { Has initiatives addressed to } \\
\text { eco-innovation, as pillars of } \\
\text { BRF sustainability, also } \\
\text { several awards addressed to } \\
\text { social and environmental } \\
\text { responsibility, as well as } \\
\text { other initiatives as animal } \\
\text { welfare, labor practices and } \\
\text { control together with the } \\
\text { suppliers. }\end{array}$ & $\begin{array}{l}\text { Has several policies } \\
\text { addressed to } \\
\text { eco-innovation, as } \\
\text { sustainability to sugar } \\
\text { and biodiesel, non- } \\
\text { deforestation, health and } \\
\text { safety, relationship with } \\
\text { suppliers, social and } \\
\text { environmental } \\
\text { responsibility and also } \\
\text { several awards and } \\
\text { certificates of } \\
\text { sustainability. }\end{array}$ & $\begin{array}{l}\text { Innovation is one of Docol } \\
\text { pillars, as it continuously } \\
\text { invests in eco-innovation, in } \\
\text { new technologies, choses the } \\
\text { best raw materials, in } \\
\text { searching for quality and } \\
\text { longevity, concern with } \\
\text { human being, social and } \\
\text { environmental initiatives and } \\
\text { several awards and certificates } \\
\text { by eco-innovation. }\end{array}$ & $\begin{array}{l}\text { Invests in innovation } \\
\text { and technology, } \\
\text { addressed to } \\
\text { sustainability and } \\
\text { continuous } \\
\text { enhancement of } \\
\text { process and } \\
\text { products, com social } \\
\text { responsibility and } \\
\text { environmental } \\
\text { projects, also has } \\
\text { several awards by } \\
\text { initiatives of } \\
\text { sustainability. }\end{array}$ & $\begin{array}{l}\text { Has several } \\
\text { environmental and } \\
\text { social practices, } \\
\text { searches constantly } \\
\text { for eco innovative } \\
\text { solutions and } \\
\text { sustainable } \\
\text { development, is } \\
\text { pioneer in several } \\
\text { technologies focus } \\
\text { on sustainability } \\
\text { and also collects } \\
\text { awards and } \\
\text { certificates by } \\
\text { sustainability. }\end{array}$ \\
\hline
\end{tabular}

Source: Data of surveyed companies (2016).

The information resulting from the interviews performed together with the five participating companies was assessed from the 27 dimensions of managerial model developed by Hansen, Grosse-Druker, \& Reichwald (2009), which determine practical implications for the management of sustainable innovations, or eco-innovations. The descriptions were made according to the information provided by companies, with the programs and projects selected, as well as according to the abundance of details that each interviewed provided. At last, the main performances and difficulties faced by companies in relation to the development of new products or processes focused to sustainability were also determined. Find below the SIC assessment model which was used in the survey, unfolded and adapted by the author of the survey, being the related and analyzed the three dimensions of the focus with the three dimensions of life cycle and afterwards, the nine outcomes produced by the three dimensions of need, thus attaining the twenty-seven dimensions of Cube as final outcome.

Table 2. SIC part 1

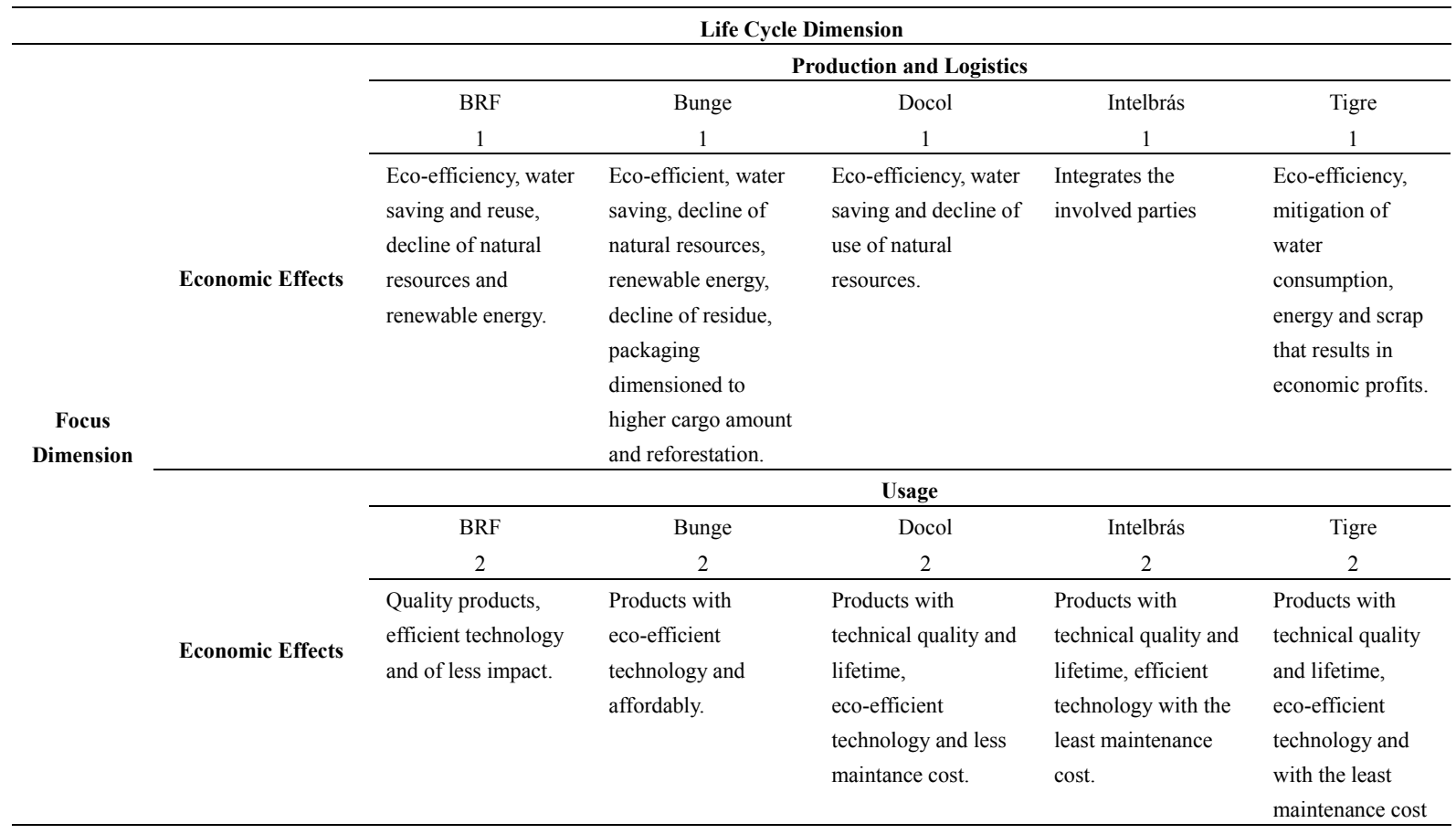




\begin{tabular}{|c|c|c|c|c|c|}
\hline \multirow[b]{4}{*}{ Economic Effects } & \multicolumn{5}{|c|}{ End-of-Life } \\
\hline & $\mathrm{BRF}$ & Bunge & Docol & Intelbrás & Tigre \\
\hline & 3 & 3 & 3 & 3 & 3 \\
\hline & $\begin{array}{l}\text { Comply with the } \\
\text { legislations in force } \\
\text { having affordable } \\
\text { landfill and upturn. }\end{array}$ & $\begin{array}{l}\text { Comply with the } \\
\text { legislations in force, } \\
\text { oil collection used to } \\
\text { reuse of new } \\
\text { products, sugarcane } \\
\text { bagasse reused for } \\
\text { energy generation, } \\
\text { turns cost into } \\
\text { revenue. }\end{array}$ & $\begin{array}{l}\text { Comply with the } \\
\text { legislations in force, } \\
\text { impact positively } \\
\text { with lifetime } \\
\text { guarantee, products } \\
\text { with high quality and } \\
\text { lifetime. }\end{array}$ & $\begin{array}{l}\text { Comply with the } \\
\text { legislations in force, } \\
\text { positively impact, } \\
\text { what is not recycled } \\
\text { goes to legal sanitary } \\
\text { or industrial } \\
\text { landfills. }\end{array}$ & $\begin{array}{l}\text { Comply with the } \\
\text { legislations in } \\
\text { force, positively } \\
\text { impact, has high } \\
\text { technical quality } \\
\text { and products } \\
\text { generating saving } \\
\text { to consumer. }\end{array}$ \\
\hline \multirow[b]{4}{*}{$\begin{array}{c}\text { Environmental } \\
\text { Effects }\end{array}$} & \multicolumn{5}{|c|}{ Production and Logistics } \\
\hline & $\mathrm{BRF}$ & Bunge & Docol & Intelbrás & Tigre \\
\hline & 4 & 4 & 4 & 4 & 4 \\
\hline & $\begin{array}{l}\text { Eco-efficiency, } \\
\text { renewable energy, } \\
\text { decline of waste of } \\
\text { water, effluents } \\
\text { treatment, recycling } \\
\text { and other practices. }\end{array}$ & $\begin{array}{l}\text { Eco-efficiency, } \\
\text { renewable energy, } \\
\text { decline of waste of } \\
\text { water, decline of } \\
\text { residue, effluents } \\
\text { treatment, reuse of } \\
\text { used oil and } \\
\text { sugarcane bagasse, } \\
\text { reforesting and other } \\
\text { practices. }\end{array}$ & $\begin{array}{l}\text { Eco-efficiency, } \\
\text { effluents treatment, } \\
\text { water saving, care } \\
\text { with the quality of air } \\
\text { and water, Eco } \\
\text { toxicity and } \\
\text { sustainable } \\
\text { construction } \\
\text { programs. }\end{array}$ & $\begin{array}{l}\text { Efficiency, have } \\
\text { effluents treatment, } \\
\text { water saving, saving } \\
\text { of natural resources. }\end{array}$ & $\begin{array}{l}\text { Eco-efficiency, } \\
\text { with energetic } \\
\text { efficiency, water } \\
\text { saving, and } \\
\text { incentives to } \\
\text { sustainable } \\
\text { construction }\end{array}$ \\
\hline \multirow[b]{4}{*}{$\begin{array}{c}\text { Environmental } \\
\text { Effects }\end{array}$} & \multicolumn{5}{|c|}{ Usage } \\
\hline & $\mathrm{BRF}$ & Bunge & Docol & Intelbrás & Tigre \\
\hline & 5 & 5 & 5 & 5 & 5 \\
\hline & $\begin{array}{l}\text { Impact positively in } \\
\text { environment, but } \\
\text { food is difficult to } \\
\text { measure due to } \\
\text { lifetime and } \\
\text { maintenance. }\end{array}$ & $\begin{array}{l}\text { Leads and } \\
\text { contributes to } \\
\text { education and care } \\
\text { with the environment } \\
\text { together with its } \\
\text { producers and } \\
\text { suppliers, impact } \\
\text { positively, but food } \\
\text { is difficult to } \\
\text { measure due to } \\
\text { lifetime and } \\
\text { maintenance. }\end{array}$ & $\begin{array}{l}\text { Products with } \\
\text { lifetime guarantee, } \\
\text { lifetime and little } \\
\text { maintenance. }\end{array}$ & $\begin{array}{l}\text { Products use low } \\
\text { energy, quality, } \\
\text { lifetime and less } \\
\text { maintenance cost. }\end{array}$ & $\begin{array}{l}\text { Lasting products, } \\
\text { with energetic } \\
\text { efficiency and } \\
\text { less maintenance } \\
\text { cost. }\end{array}$ \\
\hline \multirow[b]{4}{*}{$\begin{array}{c}\text { Environmental } \\
\text { Effects }\end{array}$} & \multicolumn{5}{|c|}{ End-of-Life } \\
\hline & $\mathrm{BRF}$ & Bunge & Docol & Intelbrás & Tigre \\
\hline & 6 & 6 & 6 & 6 & 6 \\
\hline & $\begin{array}{l}\text { Packings still not } \\
\text { proper, even } \\
\text { fulfilling the rules in } \\
\text { force. Company has } \\
\text { been working in the } \\
\text { reverse logistic } \\
\text { program of } \\
\text { post-consumption } \\
\text { packings. }\end{array}$ & $\begin{array}{l}\text { Reuse oil used in } \\
\text { homes and } \\
\text { restaurants to } \\
\text { manufacture } \\
\text { biodiesel and soap, } \\
\text { turns the sugarcane } \\
\text { bagasse of its sugar } \\
\text { plants into energy, } \\
\text { reforesting programs } \\
\text { and environmental } \\
\text { education. }\end{array}$ & $\begin{array}{l}\text { Lifetime and clean } \\
\text { production, } \\
\text { motivates and } \\
\text { encourages water } \\
\text { saving in } \\
\text { constructions. }\end{array}$ & $\begin{array}{l}\text { Eco-efficiency, care } \\
\text { with the } \\
\text { environment, lasting } \\
\text { products and cleaner } \\
\text { production, operates } \\
\text { with reverse } \\
\text { logistics and } \\
\text { recycles returning } \\
\text { materials. }\end{array}$ & $\begin{array}{l}\text { Eco-efficiency, } \\
\text { care with the } \\
\text { environment, } \\
\text { lasting products } \\
\text { and cleaner } \\
\text { production. } \\
\text { Motivates and } \\
\text { encourages water } \\
\text { saving with their } \\
\text { products. }\end{array}$ \\
\hline \multirow{4}{*}{ Social Effects } & \multicolumn{5}{|c|}{ Production and Logistics } \\
\hline & $\mathrm{BRF}$ & Bunge & Docol & Intelbrás & Tigre \\
\hline & 7 & 7 & 7 & 7 & 7 \\
\hline & $\begin{array}{l}\text { Integrates the } \\
\text { involved parties, } \\
\text { employees, }\end{array}$ & $\begin{array}{l}\text { Integrates the } \\
\text { involved parties, } \\
\text { employees, }\end{array}$ & $\begin{array}{l}\text { Integrates the } \\
\text { involved parties, } \\
\text { employees, }\end{array}$ & $\begin{array}{l}\text { Integrates the } \\
\text { involved parties, } \\
\text { clients, co-workers, }\end{array}$ & $\begin{array}{l}\text { Integrates the } \\
\text { involved parties, } \\
\text { employees, }\end{array}$ \\
\hline
\end{tabular}




\begin{tabular}{|c|c|c|c|c|c|}
\hline & $\begin{array}{l}\text { community, } \\
\text { suppliers. }\end{array}$ & $\begin{array}{l}\text { community, } \\
\text { suppliers. The } \\
\text { programs and } \\
\text { Fundação Bunge } \\
\text { ("Bunge } \\
\text { Foundation") also } \\
\text { proves that invest in } \\
\text { the development of } \\
\text { society. }\end{array}$ & $\begin{array}{l}\text { community, } \\
\text { suppliers. Programs } \\
\text { promote citizenship } \\
\text { and development of } \\
\text { society. }\end{array}$ & $\begin{array}{l}\text { shareholders, } \\
\text { community, } \\
\text { suppliers and } \\
\text { government. } \\
\text { Performs trainings } \\
\text { and campaigns with } \\
\text { co-workers so that } \\
\text { they get to know } \\
\text { procedures of } \\
\text { protection to health } \\
\text { and safety. }\end{array}$ & $\begin{array}{l}\text { community, } \\
\text { suppliers. } \\
\text { programs } \\
\text { illustrate that they } \\
\text { promote } \\
\text { development of } \\
\text { its share capital. }\end{array}$ \\
\hline \multirow[b]{4}{*}{ Social Effects } & \multicolumn{5}{|c|}{ Usage } \\
\hline & $\mathrm{BRF}$ & Bunge & Docol & Intelbrás & Tigre \\
\hline & 8 & 8 & 8 & 8 & 8 \\
\hline & $\begin{array}{l}\text { Companies and } \\
\text { programs show } \\
\text { concern regarding } \\
\text { food health and } \\
\text { safety, } 100 \% \text { of the } \\
\text { products are } \\
\text { evaluated in HACCP } \\
\text { program. }\end{array}$ & $\begin{array}{l}\text { Shows concern } \\
\text { regarding food } \\
\text { health and safety, } \\
\text { and other } \\
\text { commitments, as } \\
\text { combat against } \\
\text { humiliating job, soya } \\
\text { moratorium, natural } \\
\text { value initiative. }\end{array}$ & $\begin{array}{l}\text { Concern with health } \\
\text { and safety: to every } \\
\text { new process } \\
\text { developed, analyses } \\
\text { of impact to } \\
\text { co-workers and } \\
\text { society are made. }\end{array}$ & $\begin{array}{l}\text { Concern with } \\
\text { consumers' health } \\
\text { and safety }\end{array}$ & $\begin{array}{l}\text { Concern with } \\
\text { health and safety, } \\
\text { every process and } \\
\text { product is } \\
\text { developed to } \\
\text { provide better } \\
\text { health conditions } \\
\text { to consumers }\end{array}$ \\
\hline & \multicolumn{5}{|c|}{ End-of-Life } \\
\hline & $\begin{array}{c}\text { BRF } \\
9 \\
\end{array}$ & $\begin{array}{c}\text { Bunge } \\
9 \\
\end{array}$ & $\begin{array}{c}\text { Docol } \\
9 \\
\end{array}$ & $\begin{array}{c}\text { Intelbrás } \\
9\end{array}$ & $\begin{array}{c}\text { Tigre } \\
9 \\
\end{array}$ \\
\hline Social Effects & $\begin{array}{l}\text { Commitment in } \\
\text { sustainability, } \\
\text { education and } \\
\text { innovation. }\end{array}$ & $\begin{array}{l}\text { Involved and } \\
\text { committed to } \\
\text { sustainability, } \\
\text { education, } \\
\text { reforesting and } \\
\text { innovation }\end{array}$ & $\begin{array}{l}\text { Involved and } \\
\text { committed to } \\
\text { sustainability, } \\
\text { education and } \\
\text { innovation, } \\
\text { generating health to } \\
\text { society. }\end{array}$ & $\begin{array}{l}\text { Involved and } \\
\text { committed to } \\
\text { sustainability, } \\
\text { education and } \\
\text { innovation, } \\
\text { generating positive } \\
\text { impacts in the health } \\
\text { of society }\end{array}$ & $\begin{array}{l}\text { Involved and } \\
\text { committed to } \\
\text { sustainability, } \\
\text { education and } \\
\text { innovation, } \\
\text { generating } \\
\text { positive impacts } \\
\text { in the health of } \\
\text { society. }\end{array}$ \\
\hline
\end{tabular}

Source: Hansen, Grosse-Dunker, \& Reichwald (2009); Data from the interviews in the surveyed companies (2016).

BRF: Through the first analysis, it is possible to perceive that the company is eco-innovative in its production chain, logistics, usage, and in the three economic, environmental and social aspects. However, ending packages are under enhancement phase by means of a reverse logistics program, nevertheless it is not a practice of the company, showing that, in this specific point, the procedure still cannot be deemed as eco-innovative. According to the concepts of eco-innovation, the end of life cycle of packages should cause positive impacts, with disposal that generates economic, environmental and social value. Thus, the first analysis displays that the dimension of the end of the life cycle $\mathrm{x}$ environmental effects is not in compliance to the concepts of eco-innovation.

Bunge: The company operates with cleaner production, that is, with eco-efficiency, and also invests in the oil reverse logistics used to reuse in new products, generating income for company and positive environmental impact. As well as in the bagasse of sugarcane reuse to generate energy, being self-sufficient in power. The projects also display initiatives to reduce the environmental and social impacts, by means of environmental management, since the field up to the final consumer, and social aspects by means of projects and Fundação Bunge ("Bunge Foundation"). It also has a reforestation job, recovering degraded areas. These among other initiatives makes that the companies have a positive outcome in the first part of SIC according to the concepts of eco-innovation.

Docol: Illustrates that the economic, environmental and social dimensions are engaged in eco-innovation with a more holistic approach of the concept, as eco-innovation is present in its processes, in manufacturing, in logistics, in the products, in an institutional part and also in its services by means of manufacturing of goods and services, many times aiming at enhancing the eco-efficiency, which is certified by solutions and cleaner manufacturing technologies; reorganization of routines and structures within the sectors and new forms of management, typically in the form of dealing mainly with people and job organization; and enhancement or full development 
of new products and services. There is a strong concern with water saving and also with the longevity of its products, what confirms its eco-innovative performance, boosting both environment and society. The company demonstrated by its practices in the first SICS assessment that is committed in the life cycle of its processes and products, as well as in economic, environmental and social dimensions. These are indicatives of reducing the waste of natural resources, take care of air and water quality, of effluents treatment, the products longevity, the incentive and education to water saving, the commitment with employees' health and safety, clients and society, among other actions.

Intelbrás: Displayed that it is engaged in the SIC nine dimensions in a committed way and with advantage which helps leverage business in the segment in which it operates due to its values grounded in economic, environmental and social sustainability. The company displayed commitment with life cycle of its processes and products with initiatives of water saving, decline in the consumption of natural resources, more lasting products, investment in more efficient equipment, recycling, legal industrial landfills and whatsoever. There are projects still in progress and others awaiting investment, what makes the company take slower steps in eco-innovation journey, however solid ones. The company shows much more interest in assuming its role with society and with the future of the planet health due to an ethical issue than to display to market that it is an eco-innovative company.

Tigre: Invests and experiences eco-innovation in all nine dimensions do SIC. Further to be pioneer in several fronts addressed to eco-innovation, is concerned with value human throughout the chain, what makes it pioneer in the segment in which it operates, being in accordance to the definition of eco-innovation. Operates with eco-efficiency, focused in soften water consumption, energy and scrap, with sustainable solutions to better quality and longevity, positively impacting environment.

Table 3. SIC Part 2

\begin{tabular}{|c|c|c|c|c|c|c|c|}
\hline & & & $\mathrm{BRF}$ & Bunge & Docol & Intelbrás & Tigre \\
\hline \multirow{11}{*}{$\begin{array}{l}\text { Dimension of } \\
\text { need }\end{array}$} & Usage system & 1 & Reactive model & Pro-active model & Pro-active model & Reactive model & Pro-active model \\
\hline & Technology & 1 & $\begin{array}{l}\text { Innovations in } \\
\text { processes and } \\
\text { products }\end{array}$ & $\begin{array}{l}\text { Innovations in } \\
\text { processes and } \\
\text { products }\end{array}$ & $\begin{array}{l}\text { Innovations in } \\
\text { processes, products and } \\
\text { marketing }\end{array}$ & $\begin{array}{l}\text { Innovations in } \\
\text { processes and } \\
\text { products }\end{array}$ & $\begin{array}{l}\text { Innovations in } \\
\text { processes, } \\
\text { products and } \\
\text { marketing }\end{array}$ \\
\hline & Culture & 1 & $\begin{array}{l}\text { Innovations of } \\
\text { incremental } \\
\text { technologies }\end{array}$ & $\begin{array}{l}\text { Innovations of } \\
\text { radical and } \\
\text { incremental } \\
\text { technologies }\end{array}$ & $\begin{array}{l}\text { Innovations of radical } \\
\text { and incremental } \\
\text { technologies }\end{array}$ & $\begin{array}{l}\text { Innovations of } \\
\text { radical and } \\
\text { incremental } \\
\text { technologies }\end{array}$ & $\begin{array}{l}\text { Innovations of } \\
\text { radical and } \\
\text { incremental } \\
\text { technologies }\end{array}$ \\
\hline & Usage system & 2 & Reactive model & Pro-active model & Pro-active model & Reactive model & Pro-active model \\
\hline & Technology & 2 & $\begin{array}{l}\text { Innovations in } \\
\text { processes and } \\
\text { products }\end{array}$ & $\begin{array}{l}\text { Innovations in } \\
\text { processes and } \\
\text { products }\end{array}$ & $\begin{array}{l}\text { Innovations in } \\
\text { processes, products and } \\
\text { marketing }\end{array}$ & $\begin{array}{l}\text { Innovations in } \\
\text { processes and } \\
\text { products }\end{array}$ & $\begin{array}{l}\text { Innovations in } \\
\text { processes, } \\
\text { products and } \\
\text { marketing }\end{array}$ \\
\hline & Culture & 2 & $\begin{array}{l}\text { Innovations of } \\
\text { incremental } \\
\text { technologies }\end{array}$ & $\begin{array}{l}\text { Innovations of } \\
\text { radical and } \\
\text { incremental } \\
\text { technologies }\end{array}$ & $\begin{array}{l}\text { Innovations of radical } \\
\text { and incremental } \\
\text { technologies }\end{array}$ & $\begin{array}{l}\text { Innovations of } \\
\text { radical and } \\
\text { incremental } \\
\text { technologies }\end{array}$ & $\begin{array}{l}\text { Innovations of } \\
\text { radical and } \\
\text { incremental } \\
\text { technologies }\end{array}$ \\
\hline & Usage system & 3 & Reactive model & Pro-active model & Pro-active model & Reactive model & Pro-active model \\
\hline & Technology & 3 & $\begin{array}{l}\text { Innovations in } \\
\text { processes and } \\
\text { products }\end{array}$ & $\begin{array}{l}\text { Innovations in } \\
\text { processes and } \\
\text { products }\end{array}$ & $\begin{array}{l}\text { Innovations in } \\
\text { processes, products and } \\
\text { marketing }\end{array}$ & $\begin{array}{l}\text { Innovations in } \\
\text { processes and } \\
\text { products }\end{array}$ & $\begin{array}{l}\text { Innovations in } \\
\text { processes, } \\
\text { products and } \\
\text { marketing }\end{array}$ \\
\hline & Culture & 3 & $\begin{array}{l}\text { Innovations of } \\
\text { incremental } \\
\text { technologies }\end{array}$ & $\begin{array}{l}\text { Innovations of } \\
\text { radical and } \\
\text { incremental } \\
\text { technologies }\end{array}$ & $\begin{array}{l}\text { Innovations of radical } \\
\text { and incremental } \\
\text { technologies }\end{array}$ & $\begin{array}{l}\text { Innovations of } \\
\text { radical and } \\
\text { incremental } \\
\text { technologies }\end{array}$ & $\begin{array}{l}\text { Innovations of } \\
\text { radical and } \\
\text { incremental } \\
\text { technologies }\end{array}$ \\
\hline & Usage system & 4 & Reactive model & $\begin{array}{l}\text { Pro-active model } \\
\text { and reactive }\end{array}$ & Pro-active model & Reactive model & Pro-active model \\
\hline & Technology & 4 & $\begin{array}{l}\text { Innovations in } \\
\text { processes, } \\
\text { products and } \\
\text { marketing }\end{array}$ & $\begin{array}{l}\text { Innovations in } \\
\text { processes, } \\
\text { products and } \\
\text { marketing }\end{array}$ & $\begin{array}{l}\text { Innovations in } \\
\text { processes, products and } \\
\text { marketing }\end{array}$ & $\begin{array}{l}\text { Innovations in } \\
\text { processes and } \\
\text { products }\end{array}$ & $\begin{array}{l}\text { Innovations in } \\
\text { processes } \\
\text { products and } \\
\text { marketing }\end{array}$ \\
\hline
\end{tabular}




\begin{tabular}{|c|c|c|c|c|c|c|}
\hline Culture & 4 & $\begin{array}{l}\text { Innovations of } \\
\text { incremental } \\
\text { technologies }\end{array}$ & $\begin{array}{l}\text { Innovations of } \\
\text { radical and } \\
\text { incremental } \\
\text { technologies }\end{array}$ & $\begin{array}{l}\text { Innovations of radical } \\
\text { and incremental } \\
\text { technologies }\end{array}$ & $\begin{array}{l}\text { Innovations of } \\
\text { radical and } \\
\text { incremental } \\
\text { technologies }\end{array}$ & $\begin{array}{l}\text { Innovations of } \\
\text { radical and } \\
\text { incremental } \\
\text { technologies }\end{array}$ \\
\hline Usage system & 5 & Reactive model & Pro-active model & Pro-active model & Reactive model & Pro-active model \\
\hline Technology & 5 & $\begin{array}{l}\text { Innovations in } \\
\text { processes, } \\
\text { products and } \\
\text { marketing }\end{array}$ & $\begin{array}{l}\text { Innovations in } \\
\text { processes, } \\
\text { products and } \\
\text { marketing }\end{array}$ & $\begin{array}{l}\text { Innovations in } \\
\text { processes, products and } \\
\text { marketing }\end{array}$ & $\begin{array}{l}\text { Innovations in } \\
\text { processes and } \\
\text { products }\end{array}$ & $\begin{array}{l}\text { Innovations in } \\
\text { processes, } \\
\text { products and } \\
\text { marketing }\end{array}$ \\
\hline Culture & 5 & $\begin{array}{l}\text { Innovations of } \\
\text { incremental } \\
\text { technologies }\end{array}$ & $\begin{array}{l}\text { Innovations of } \\
\text { radical and } \\
\text { incremental } \\
\text { technologies }\end{array}$ & $\begin{array}{l}\text { Innovations of radical } \\
\text { and incremental } \\
\text { technologies }\end{array}$ & $\begin{array}{l}\text { Innovations of } \\
\text { radical and } \\
\text { incremental } \\
\text { technologies }\end{array}$ & $\begin{array}{l}\text { Innovations of } \\
\text { radical and } \\
\text { incremental } \\
\text { technologies }\end{array}$ \\
\hline Usage system & 6 & Reactive model & $\begin{array}{l}\text { Pro-active model } \\
\text { and reactive }\end{array}$ & Pro-active model & Reactive model & Pro-active model \\
\hline Technology & 6 & $\begin{array}{l}\text { Innovations in } \\
\text { processes }\end{array}$ & $\begin{array}{l}\text { Innovations in } \\
\text { processes, } \\
\text { products and } \\
\text { marketing }\end{array}$ & $\begin{array}{l}\text { Innovations in } \\
\text { processes, products and } \\
\text { marketing }\end{array}$ & $\begin{array}{l}\text { Innovations in } \\
\text { processes and } \\
\text { products }\end{array}$ & $\begin{array}{l}\text { Innovations in } \\
\text { processes, } \\
\text { products and } \\
\text { marketing }\end{array}$ \\
\hline Culture & 6 & $\begin{array}{l}\text { Innovations of } \\
\text { incremental } \\
\text { technologies }\end{array}$ & $\begin{array}{l}\text { Innovations of } \\
\text { radical and } \\
\text { incremental } \\
\text { technologies }\end{array}$ & $\begin{array}{l}\text { Innovations of radical } \\
\text { and incremental } \\
\text { technologies }\end{array}$ & $\begin{array}{l}\text { Innovations of } \\
\text { radical and } \\
\text { incremental } \\
\text { technologies }\end{array}$ & $\begin{array}{l}\text { Innovations of } \\
\text { radical and } \\
\text { incremental } \\
\text { technologies }\end{array}$ \\
\hline Usage system & 7 & Reactive model & Pro-active model & Pro-active model & Reactive model & Pro-active model \\
\hline Technology & 7 & $\begin{array}{l}\text { Innovations in } \\
\text { processes and } \\
\text { products }\end{array}$ & $\begin{array}{l}\text { Innovations in } \\
\text { processes and } \\
\text { products }\end{array}$ & $\begin{array}{l}\text { Innovations in } \\
\text { processes, products and } \\
\text { marketing }\end{array}$ & $\begin{array}{l}\text { Innovations in } \\
\text { processes and } \\
\text { products }\end{array}$ & $\begin{array}{l}\text { Innovations in } \\
\text { processes, } \\
\text { products and } \\
\text { marketing }\end{array}$ \\
\hline Culture & 7 & $\begin{array}{l}\text { Innovations of } \\
\text { incremental } \\
\text { technologies }\end{array}$ & $\begin{array}{l}\text { Innovations of } \\
\text { radical and } \\
\text { incremental } \\
\text { technologies }\end{array}$ & $\begin{array}{l}\text { Innovations of radical } \\
\text { and incremental } \\
\text { technologies }\end{array}$ & $\begin{array}{l}\text { Innovations of } \\
\text { radical and } \\
\text { incremental } \\
\text { technologies }\end{array}$ & $\begin{array}{l}\text { Innovations of } \\
\text { radical and } \\
\text { incremental } \\
\text { technologies }\end{array}$ \\
\hline Usage system & 8 & Reactive model & Pro-active model & Pro-active model & Reactive model & Pro-active model \\
\hline Technology & 8 & $\begin{array}{l}\text { Innovations in } \\
\text { processes and } \\
\text { products }\end{array}$ & $\begin{array}{l}\text { Innovations in } \\
\text { processes and } \\
\text { products }\end{array}$ & $\begin{array}{l}\text { Innovations in } \\
\text { processes, products and } \\
\text { marketing }\end{array}$ & $\begin{array}{l}\text { Innovations in } \\
\text { processes and } \\
\text { products }\end{array}$ & $\begin{array}{l}\text { Innovations in } \\
\text { processes, } \\
\text { products and } \\
\text { marketing }\end{array}$ \\
\hline Culture & 8 & $\begin{array}{l}\text { Innovations of } \\
\text { incremental } \\
\text { technologies }\end{array}$ & $\begin{array}{l}\text { Innovations of } \\
\text { radical and } \\
\text { incremental } \\
\text { technologies }\end{array}$ & $\begin{array}{l}\text { Innovations of radical } \\
\text { and incremental } \\
\text { technologies }\end{array}$ & $\begin{array}{l}\text { Innovations of } \\
\text { radical and } \\
\text { incremental } \\
\text { technologies }\end{array}$ & $\begin{array}{l}\text { Innovations of } \\
\text { radical and } \\
\text { incremental } \\
\text { technologies }\end{array}$ \\
\hline Usage system & 9 & Reactive model & Pro-active model & Pro-active model & Reactive model & Pro-active model \\
\hline Technology & 9 & $\begin{array}{l}\text { Innovations in } \\
\text { processes and } \\
\text { products }\end{array}$ & $\begin{array}{l}\text { Innovations in } \\
\text { processes and } \\
\text { products }\end{array}$ & $\begin{array}{l}\text { Innovations in } \\
\text { processes, products and } \\
\text { marketing }\end{array}$ & $\begin{array}{l}\text { Innovations in } \\
\text { processes and } \\
\text { products }\end{array}$ & $\begin{array}{l}\text { Innovations in } \\
\text { processes, } \\
\text { products and } \\
\text { marketing }\end{array}$ \\
\hline Culture & 9 & $\begin{array}{l}\text { Innovations of } \\
\text { incremental } \\
\text { technologies }\end{array}$ & $\begin{array}{l}\text { Innovations of } \\
\text { radical and } \\
\text { incremental } \\
\text { technologies }\end{array}$ & $\begin{array}{l}\text { Innovations of radical } \\
\text { and incremental } \\
\text { technologies }\end{array}$ & $\begin{array}{l}\text { Innovations of } \\
\text { radical and } \\
\text { incremental } \\
\text { technologies }\end{array}$ & $\begin{array}{l}\text { Innovations of } \\
\text { radical and } \\
\text { incremental } \\
\text { technologies }\end{array}$ \\
\hline
\end{tabular}

Source: Hansen, Grosse-Dunker, \& Reichwald (2009); Manual do Oslo (2005); Data of surveyed companies (2016).

In the second part of the analysis, according to the 27 dimensions, the companies which are eco-innovative by their initiatives and practices of continuous innovation in searching for lesser impacts to environment. The companies are coherent with the definition of eco-innovation, which comprises several innovative practices that matches economic and ecological benefits in resources (LEVIDOW et al., 2016). It is possible to notice that every company has a profile regarding the dimension of the need, due to strategy and positioning of each of them, being more conservative or audacious in investment in eco-innovation. 


\section{Discussion}

The present paper aimed at (1) analyzing the level of companies' eco-innovation which operate in international market according to the Sustainability Innovation Cube (SIC) model developed by Hansen, Grosse-Dunker, \& Reichwald (2009), so as to reveal a factor of competitiveness in the international market.

According to the assurance of all companies' interviewers, the adoption of practices addressed to eco-innovation results in potential positive impacts and provides more competitiveness to the companies. For this reason, investments addressed to this area grow even more, in searching for better performance in the international market, which is more demanding in consumption standards, creating value to companies and consolidating the international credibility.

All five companies analyzed notice that the eco-innovation provides competitive position at long term, as the companies realize that they need to reduce the consumption of non-renewable natural resources, and the waste of those raw-materials must be restrained by means of renewable alternatives, the disposal of their processes and products appropriately to attain positive impacts, as well as meet their social responsibility.

The companies analyzed showed to keep a more intense integration with stakeholders regarding the outcomes resulting from investment in eco-innovation, as, according to the interviewers, add in image and value of the companies, resulting in higher competitiveness regarding international market.

Information gathered displays that eco-innovation is a journey to corporations which search to positively impact the economic, environmental and social aspects, as in the table below.

Table 4. Company's results

\begin{tabular}{|c|c|c|c|c|c|}
\hline & BRF & Bunge & Docol & Intelbrás & Tigre \\
\hline $\begin{array}{l}\text { Usage-Before the market } \\
\text { and the strategies, every } \\
\text { company has methods and } \\
\text { specific needs to develop } \\
\text { eco-innovation, in search } \\
\text { and more competitive } \\
\text { products and market } \\
\text { leadership. }\end{array}$ & $\begin{array}{l}\text { Strategy to attain better } \\
\text { finance outcomes and } \\
\text { comply with the trend of } \\
\text { "sustainable" market. }\end{array}$ & $\begin{array}{l}\text { Strategic tool for } \\
\text { positioning and products } \\
\text { grounded on } \\
\text { sustainability which } \\
\text { aggregate value to } \\
\text { company and society. }\end{array}$ & $\begin{array}{l}\text { Strategic tool for } \\
\text { positioning and products } \\
\text { grounded on } \\
\text { sustainability which } \\
\text { aggregate value to } \\
\text { company and society. }\end{array}$ & $\begin{array}{l}\text { By ethics and concern } \\
\text { with environment and } \\
\text { future generation. }\end{array}$ & $\begin{array}{l}\text { Strategic tool for } \\
\text { positioning and } \\
\text { products grounded } \\
\text { on sustainability } \\
\text { which aggregate } \\
\text { value to company } \\
\text { and society. }\end{array}$ \\
\hline $\begin{array}{l}\text { Level of } \\
\text { eco-innovation-Analysis } \\
\text { of SIC, documents, } \\
\text { websites and projects and } \\
\text { programs of companies. }\end{array}$ & $\begin{array}{l}\text { It presents itself with } \\
\text { high degree of } \\
\text { eco-innovation with } \\
\text { exception of products } \\
\text { life cycle, as it in } \\
\text { development of package } \\
\text { which have positive } \\
\text { impact to the } \\
\text { environment by means } \\
\text { of reverse logistics. }\end{array}$ & $\begin{array}{l}\text { It presents itself with } \\
\text { high degree of } \\
\text { eco-innovation in the } 27 \\
\text { dimensions, as it works } \\
\text { the issue since the } \\
\text { beginning of its } \\
\text { operation, invests and } \\
\text { uses eco-efficiency in } \\
\text { the processes and } \\
\text { products, with } \\
\text { pro-active to market in } \\
\text { search to generate } \\
\text { positive impacts to } \\
\text { society and leadership in } \\
\text { segment. }\end{array}$ & $\begin{array}{l}\text { It presents itself with } \\
\text { high degree of } \\
\text { eco-innovation in the } 27 \\
\text { dimensions, as it works } \\
\text { the issue since the } \\
\text { beginning of its } \\
\text { operation, invests and } \\
\text { uses eco-efficiency in } \\
\text { the processes and } \\
\text { products, with } \\
\text { pro-active to market in } \\
\text { search to generate } \\
\text { positive impacts to } \\
\text { society and leadership in } \\
\text { segment. }\end{array}$ & $\begin{array}{l}\text { It presents itself with high } \\
\text { degree of eco-innovation, } \\
\text { but it is new in its } \\
\text { initiatives, materializes its } \\
\text { projects according to } \\
\text { planning of the company. } \\
\text { New technological } \\
\text { paradigms are not part of } \\
\text { its performance, as it } \\
\text { already defined itself as } \\
\text { technology follower, but } \\
\text { adapt technology created } \\
\text { to be well explored, } \\
\text { enjoyed and pulverized in } \\
\text { market. }\end{array}$ & $\begin{array}{l}\text { It presents itself with } \\
\text { high degree of } \\
\text { eco-innovation in the } \\
27 \text { dimensions, as it } \\
\text { works the issue since } \\
\text { the beginning of its } \\
\text { operation, invests } \\
\text { and uses } \\
\text { eco-efficiency in the } \\
\text { processes and } \\
\text { products, with } \\
\text { pro-active to market } \\
\text { in search to generate } \\
\text { positive impacts to } \\
\text { society and } \\
\text { leadership in } \\
\text { segment. }\end{array}$ \\
\hline $\begin{array}{l}\text { Initiatives - The survey } \\
\text { brings evidence of the } \\
\text { initiatives of the company. }\end{array}$ & $\begin{array}{l}\text { Its initiative in } \\
\text { eco-innovation is to } \\
\text { follow a trend or } \\
\text { requirement demanded } \\
\text { by the side of the } \\
\text { market, which is, } \\
\text { passively, focused on the } \\
\text { outcomes. }\end{array}$ & $\begin{array}{l}\text { Eco-innovate by own } \\
\text { initiative, by strategy } \\
\text { and positioning of the } \\
\text { company and their } \\
\text { products of the segment }\end{array}$ & $\begin{array}{l}\text { Eco-innovate by own } \\
\text { initiative, by strategy } \\
\text { and positioning of the } \\
\text { company and their } \\
\text { products of the segment }\end{array}$ & $\begin{array}{l}\text { Innovates strategically, as } \\
\text { its segment is technology, } \\
\text { however eco-innovate is } \\
\text { not an initiative by } \\
\text { external pressure, as } \\
\text { mentioned by E5, but by } \\
\text { own initiative, by ethical } \\
\text { issues of the company, to } \\
\text { contribute with the planet } \\
\text { health, by awareness and } \\
\text { social and economic } \\
\text { commitment. }\end{array}$ & $\begin{array}{l}\text { Eco-innovate by } \\
\text { own initiative, by } \\
\text { strategy and } \\
\text { positioning of the } \\
\text { company and their } \\
\text { products of the } \\
\text { segment }\end{array}$ \\
\hline
\end{tabular}




\begin{tabular}{|c|c|c|c|c|c|}
\hline $\begin{array}{l}\text { SIC-Tool Sustainable } \\
\text { Innovation Cube. }\end{array}$ & $\begin{array}{l}\text { Follows technology in } \\
\text { eco-innovation, as it } \\
\text { does not affect market } \\
\text { with new technological } \\
\text { paradigms, but meets the } \\
\text { requirement needs of the } \\
\text { market adapting the } \\
\text { existing technologies. }\end{array}$ & $\begin{array}{l}\text { Fulfills actively with the } \\
\text { eco-innovation agenda } \\
\text { in SIC } 27 \text { dimensions. }\end{array}$ & $\begin{array}{l}\text { Fulfills actively with the } \\
\text { eco-innovation agenda } \\
\text { in SIC } 27 \text { dimensions. }\end{array}$ & $\begin{array}{l}\text { Follows technology in } \\
\text { eco-innovation, as it does } \\
\text { not affect market with } \\
\text { new technological } \\
\text { paradigms, but meets the } \\
\text { requirement needs of the } \\
\text { market adapting the } \\
\text { existing technologies. }\end{array}$ & $\begin{array}{l}\text { Fulfills actively with } \\
\text { the eco-innovation } \\
\text { agenda in SIC } 27 \\
\text { dimensions. }\end{array}$ \\
\hline $\begin{array}{l}\text { Marketing-Regarding } \\
\text { the efforts of the } \\
\text { companies searching for } \\
\text { the construction of } \\
\text { marketing addressed to } \\
\text { eco-innovation. }\end{array}$ & Term is still unknown. & $\begin{array}{l}\text { The awareness of the } \\
\text { issue displays itself in a } \\
\text { more developed form. }\end{array}$ & $\begin{array}{l}\text { The awareness of the } \\
\text { issue displays itself in a } \\
\text { more developed form. }\end{array}$ & Term is still unknown. & $\begin{array}{l}\text { The awareness of the } \\
\text { issue displays itself } \\
\text { in a more developed } \\
\text { form. }\end{array}$ \\
\hline $\begin{array}{l}\text { Suggestions-Regarding } \\
\text { in what could be enhanced } \\
\text { to process of the } \\
\text { companies to evolve in the } \\
\text { eco-innovation walk }\end{array}$ & $\begin{array}{l}\text { Positively impact in } \\
\text { packing proper disposal. } \\
\text { Produce less with less. }\end{array}$ & Produce less with less. & Produce less with less. & $\begin{array}{l}\text { Operate with } \\
\text { eco-efficiency in all its } \\
\text { processes. Produce less } \\
\text { with less. }\end{array}$ & $\begin{array}{l}\text { Produce less with } \\
\text { less. }\end{array}$ \\
\hline
\end{tabular}

Information collected points out to possible discrepancies regarding practices of company BRF, as, according to notice of Federal Police previously mentioned, the company might be placing the health and safety of their consumers at risk. Nevertheless, the case is still being investigated and might be examined in future surveys.

"Public agents, using the supervision power of the position, before payment of bribery, operate to facilitate the production of adulterated food, issuing sanitary certificates without no duly supervision. Among the unlawfulness practiced in the ambit of public sector, one denotes the removal of public agents, with deviation of purpose to meet interests of corporate groups. Such a behavior would allow the criminal continuity of cold storage companies and food segment companies which operate in total breach to legislation in force (Federal Police of Brazil, 2017).

On the whole, the main difficulties faced by companies concerning inclusion of the principles of sustainability in their activities of innovation, or eco-innovation can be attributed to lack of awareness regarding the market opportunities that eco-innovation may offer, by the focus on the outcomes at short term, likewise that the few resources finance addressed to this kind of innovation, treated as high risk or many times of high values for the planning of the companies.

According to the interviewers, as it is addressing to large-sized companies, the commitment with eco-innovation is fundamental in the operations of international market; however, there is still incipiency of some regarding the adoption of managerial practices addressed to development of innovations addressed to sustainability, or eco-innovation, what makes the SIC application even richer and necessary with more detailed and specific information to guide managers in their decision making.

\subsection{Restrains and Challenges of the Study as Well as Future Researches}

This study, as well as any other research in social sciences, illustrates restrains not only in its application but also in the analysis of its outcomes. Among such restrains, the generalization of it outcomes, as it goes through five companies from different segments and in a certain time, describing a particular reality of the population investigated. Study restrain would be based on the perception of the responsible managers for eco-innovation management of the companies researched, in the possible practices experienced by the companies regarding eco-innovation, having as reference the competitiveness in performance in international market. Data collection also shows restrains regarding time and availability of the interviewed, as well as disclosure of strategic confidential data and accurate information.

For the development of future researches, it would be interesting to elaborate a quantitative research for a wider assessment of consumer behavior before eco-innovation actions, or a mixed research in the same companies with a larger population of interviews to better measure the eco-innovation activities in each of them and, as a result, better assess the relation between eco-innovation e competitiveness in international market.

\section{References}

Adams, R., Jeanrenaud, S., Bessant, J., Denyer, D., \& Overy, P. (2016). Sustainability-oriented Innovation: A Systematic Review. International Journal of Management Reviews, 18(2), 180-205. https://doi.org/10.1111/ijmr.12068 
Aghion, P., Blundell, R., Griffith, R., Howitt, P., \& Prantl, S. (2009). The Effects of Entry on Incumbent Innovation and Productivity. Review of Economics and Statistics, 91(1), 20-32. https://doi.org/10.1162/rest.91.1.20

Bell, M., \& Pavitt, K. (1995). The Development of Technological Capabilities. Trade, Technology and International Competitiveness (p. 232).

Bocken, N. M. P., \& Short, S. W. (2016). Towards a sufficiency-driven business model: Experiences and opportunities. Environmental Innovation and Societal Transitions, 18, 41-61. https://doi.org/10.1016/j.eist.2015.07.010

Boons, F., Montalvo, C., Quist, J., \& Wagner, M. (2013). Sustainable innovation, business models and economic performance: An overview. Journal of Cleaner Production, 45, 1-8. https://doi.org/10.1016/j.jclepro.2012.08.013

Brundtland, G. H. (1997). The scientific underpinning of policy. Science, 277(5325), 457. https://doi.org/10.1126/science.277.5325.457

Cai, W. G., \& Zhou, X. L. (2014). On the drivers of eco-innovation: Empirical evidence from China. Journal of Cleaner Production, 79, 239-248. https://doi.org/10.1016/j.jclepro.2014.05.035

Carrillo-Hermosilla, J., Del Río, P., \& Könnölä, T. (2010). Diversity of eco-innovations: Reflections from selected case studies. Journal of Cleaner Production, 18(10-11), 1073-1083. https://doi.org/10.1016/j.jclepro.2010.02.014

Cohen, W. M., \& Levinthal, D. A. (1990). Absorptive Capacity: A New Perspective on Learning and Innovation. Administrative Science Quarterly, 35(1), 128. https://doi.org/10.2307/2393553

Creswel, J. W. (2013). Projeto de pesquisa: métodos qualitativo, quantitativo e misto (3rd ed.). Porto Alegre: Artmed.

Druckman, A., Chitnis, M., Sorrell, S., \& Jackson, T. (2011). Missing carbon reductions? Exploring rebound and backfire effects in UK households. Energy Policy, 39(6), 3572-3581. https://doi.org/10.1016/j.enpol.2011.03.058

Dyllick, T., Hockerts, K., \& Thomas Dyllick, K. H. (2002). Beyond the business case for corporate sustainability. Business Strategy and the Environment, 11(2), 130-141. https://doi.org/10.1002/bse.323

Epicoco, M., Oltra, V., \& Saint Jean, M. (2014). Knowledge dynamics and sources of eco-innovation: Mapping the Green Chemistry community. Technological Forecasting and Social Change, 81(1), 388-402. https://doi.org/10.1016/j.techfore.2013.03.006

European Commission. (2008). Call for Proposals under the Eco-innovation 2008 Programme. DG Environment. Retrieved from http://ec.europa.eu/environment/etap/ecoinnovation/ library_en.htm

Figueiredo, P. N. (2013). Gestão da inovação: conceitos, métricas e experiências de empresas no Brasil. Rio de Janeiro: LTC.

Fontana, A., \& Frey, J. H. (1994). Interviewing: The Arts of Science. Handbook of Qualitative Research, $i$, 361-376. https://doi.org/10.1016/j.jconhyd.2010.08.009

Freitas, P. P. (2014). Marketing Verde: Algumas Contradições do Discurso Ambiental. VI Congreso Iberoamericano de Estúdios Territoriales y ambientales, pp. 4693-4708.

Fundação Getúlio Vargas (FGV). (2011). Contribuições do $1^{\circ}$ grupo de trabalho GVces sobre a ISO 26000. A norma internacional de responsabilidade social. São Paulo: Vox Editora.

Gil, A. C. (2009). Como elaborar projetos de pesquisa (4th ed.). São Paulo: Atlas.

Gilding, P. (2014). A Grande Ruptura: Como a crise climática vai acabar com o consumo e criar um novo mundo (1st ed.). Rio de Janeiro: Apicuri.

Hansen, E. G., \& Klewitz, J. (2012). The Role of an SME's Green Strategy in Public-Private Eco-Innovation Initiatives: The Case of Ecopro. Journal of Small Business \& Entrepreneurship, 25(4), 37-41.

Hansen, E. G., Grosse-Dunker, F., \& Reichwald, R. (2009). Sustainability Innovation Cube-a Framework to Evaluate Sustainability-Oriented Innovations. International Journal of Innovation Management, 13(4), 683-713. https://doi.org/10.1142/S1363919609002479

Huppes, G., Koning, A., Suh, S., Heijungs, R., Oers, L., Nielsen, P., \& Guinée, J. B. (2006). Environmental 
Impacts of Consumption in the European Union: High-Resolution Input-Output Tables with Detailed Environmental Extensions. Journal of Industrial Ecology, 10(3), 129-146. https://doi.org/10.1162/jiec.2006.10.3.129

Leach, M., Rockström, J., Raskin, P., Scoones, I., Stirling, A. C., Smith, A., ... Olsson, P. (2012). Transforming innovation for sustainability. Ecology and Society, 17(2). https://doi.org/org/10.5751/ES-04933-170211

Levidow, L., Lindgaard-Jørgensen, P., Nilsson, Å., Skenhall, S. A., \& Assimacopoulos, D. (2016). Process eco-innovation: Assessing meso-level eco-efficiency in industrial water-service systems. Journal of Cleaner Production, 110, 54-65. https://doi.org/10.1016/j.jclepro.2014.12.086

Magretta, J. (2002). Why business models matter. Harvard Business Review. https://doi.org/10.1002/1099-0690(200112)2001:23<4391: AID-EJOC4391>3.0.CO;2-D

Maniglia, E., \& Costa, Y. F. da. (2012). Direito e Politicas Publicas de Sustentabilidade (2nd ed.). Ribeirão Preto: Legis Summa.

Manual do Oslo. (2005). Diretrizes para coleta e interpretação de dados sobre inovação (3rd ed.). OECD.

Melo, N., Francisco, P., \& Brennand, J. M. (2004). Empresas Socialmente Sustentáveis: O Novo Desafio de Gestão Moderna (1st ed.). Rio de Janeiro: Qualitymark.

Munck, L., Galleli, B., \& Souza, R. De. (2012). Competências para a sustentabilidade organizacional: a proposição de um framework representativo do acontecimento da ecoeficiência. SciELO Brasil, 18. http://dx.doi.org/10.1590/S0103-65132013005000004

Murad, E. G., Amaral, F. N., \& Boff, E. (2013). Comunicação Organizacional Verde: Economia, marketing ambiental \& diálogo social para a sustentabilidade corporativa (1st ed.). Rio de Janeiro: Editório.

Nascimento, E. P. do. (2012). Trajetória da sustentabilidade: do ambiental ao social, do social ao econômico. Estudos Avançados, 26(74), 51-64. https://doi.org/10.1590/S0103-40142012000100005

OROSKI, F. A. (2013). Modelos de Negócio e Transição de Sistemas Tecnológicos: o caso dos bioplásticos, xv, 195 f.: il. Tese Doutorado em Tecnologia de Processos Químicos e Bioquímicos-Universidade Federal do Rio de Janeiro, Rio de Janeiro, RJ, Brasil.

Oroski, F. A. (2013). Modelos de Negócio e Transição de Sistemas Tecnológicos: o caso dos bioplásticos, xv, 195 f.: il. Tese Doutorado em Tecnologia de Processos Químicos e Bioquímicos-Universidade Federal do Rio de Janeiro, Rio de Janeiro, RJ, Brasil.

Policia Federal do Brasil. Notícias. (2017). Retrieved from http://www.pf.gov.br/agencia/noticias/2017/03/pf-desarticula-esquema-criminoso-envolvendo-agentes-publi cos-e-empresarios

Queiroz, L. L. (2014). Utopia da Sustentabilidade e Transgressões do Design (1st ed.). Rio de Janeiro: 7 Letras.

Roscoe, S., Cousins, P. D., \& Lamming, R. C. (2016). Developing eco-innovations: A three-stage typology of supply networks. Journal of Cleaner Production, 112, 1948-1959. https://doi.org/10.1016/j.jclepro.2015.06.125

Schaltegger, S., \& Wagner, M. (2008). Types of sustainable entrepreneurship and conditions for sustainability innovation: from the administration of a technical challenge to the management of an entrepreneurial opportunity. Sustainable Innovation and Entrepreneurship, https://doi.org/10.4337/9781848441552.00009

Schaltegger, S., Freund, F. L., \& Hansen, E. G. (2012). Business cases for sustainability: the role of business model innovation for corporate sustainability. International Journal of Innovation and Sustainable Development, 6(2), 95. https://doi.org/10.1504/IJISD.2012.046944

Schumpeter, J. (1934). The Theory of Economic Development. An Inquiry into Profits, Capital, Credit, Interest, and the Business. Cambridge, MA: Harvard University Press. Retrieved from https://books.google.co.uk/books?id=7p9fwYiDR20C\&dq=The+Theory+of+Economic+Development

Tachizawa, T., \& Pozo, H. (2007). Gestão socioambiental e desenvolvimento sustentável: um indicador para avaliar a sustentabilidade empresarial. REDE-Revista Eletrônica Do Prodema, 1, 35-54.

Teece, D. (2005). Dynamic capabilities and strategic management. On Business and Management, 18(7), 509-533.

Retrieved

from http://scholar.google.com/scholar?hl=en\&btnG=Search\&q=intitle:Dynamic+Capabilities+and + Strategic $+\mathrm{M}$ 


\section{anagement $\# 0$}

Tidd, J., \& Bessant, J. (2015). Gestão da Inovação. Tradução: [Felix Nonnenmacher] (5th ed.). Porto Alegre: Bookman.

Tigre, P. B. (2006). Gestão da Inovação: a economia da tecnologia do Brasil (5th ed.). Rio de Janeiro: Elsevier.

Triguero, A., Moreno-Mondéjar, L., \& Davia, M. A. (2013). Drivers of different types of eco-innovation in European SMEs. Ecological Economics, 92, 25-33. https://doi.org/10.1016/j.ecolecon.2013.04.009

UNFCC - United Nations Framework Convention on Climate Change. Kyoto Protocol to the United Nations Framework Convetion on Climate Change. (2015). United Nations, 1998. Retrieved from http://unfecc.int/resource/docs/convkp/kpeng.pdf

Yin, R. K. (2003). Estudo de caso: planejamento e métodos (2nd ed.). Porto Alegre: Bookman.

\section{Copyrights}

Copyright for this article is retained by the author(s), with first publication rights granted to the journal.

This is an open-access article distributed under the terms and conditions of the Creative Commons Attribution license (http://creativecommons.org/licenses/by/4.0/). 